\title{
有限要素法による塊状磁極同期電動機の 磁極部発生損失
}

$\begin{array}{llllll}\text { 正員 } & \text { 山 } & \text { 田 } & \text { 速敏 } & \text { (埼玉大) } \\ \text { 准 員 } & \text { 金 } & \text { 井 } & & \text { 均 } & \text { (埼玉大) } \\ \text { 正員 } & \text { 伊 } & \text { 藤 } & & \text { 馨 } & \text { (東京芝浦電気) } \\ \text { 正 } & \text { 中 } & \text { 野 } & \text { 正 } & \text { 允 } & \text { (東京芝浦電気) }\end{array}$

\section{1. まえがき}

近年, 有限要菜法による解析法が変圧器および回転 機の分野において適用されているが，有限要素法によ る解析の利点は; 解析解が容易に求めがたい構造が複 雑な形状に対して計算が可能である点にあると考えら れる。

突極形塊状磁極同期電動機は積層磁極の同期電動機 とは異なり，磁極内の電流分布が複雑であるここから 末だ詳細に解決しなりればならない点が数多く残され ている(1) (6)。

限界設漂に伴って，より精密な計算精度の向上が必 要となる。信頼性の向上と, 絶縁設計とに関連して, 非同期運転時における塊状磁極同期電動機の磁極部の 温度分布を詳しく知る必要がある。すなおち，塊状磁 極部の磁極内部に発生する損失を詳しく知る必要があ る。

本諭文は有限要素法によって始動時に抢ける磁極内 部の発生損失を求めたすのである。

また，有限要素法によって求められた発生損失之， 均質形塊状鉄心誘導電動機化打ける損失分布と比較し 一般的な設計指針を得ることを目的として考察を行な っている。

本論文では有限要素法によって，塊状磁極同期電動

Loss Calculation in Solid Pole Salient Machine by Finite Element Method at Asynchronous Operation. By Hayatoshi Yamada, Member, Hitoshi Kanai, Associate (Faculty of Engineering, Saitama University), Kaotu Ito, Member \& Masachika Nakano, Member (Toshiba Corporation), 山田速敏：正昷，埼互大学工学部電気工学移

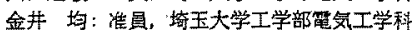

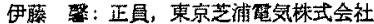
中野正台：正員，東京芝浦電気株式会社
機の磁極部の磁束分布を求めた。また、ベクトルポデ ンシャルと磁極内に発生する挰失との関倸を理論的に 考察し, 磁極内部の損失分布を求めている。固定子内 面に境界值しして与えるエアギャップ部の磁束密度は 直軸等価回路，および横軸等価回路 ${ }^{(6)}$ における一次イ ンピーダンス電王降下を考㯺して求めている。

非同期運転時におけ石基本波成分の損失分布知る ことと，発生トルクを知ることとはお互いに関連があ る。有限要素法によるトルク計算結果と実測值との比 較を行なった結果，すべり 0.5 付近を除いては測定結 果と合うことを確かめた。

回転子か内筒形状の塊状鉄心誘導電動機の場合には 発生損失の解新解が得られている(7) (韭線形理論)。し 加しがら，復雑な磁極形状を有する塊状磁極同期電 動機の発生損失の解析解は従来求められていない。塊 状磁檀部について，有限要素法の解析結果より，発生 損失の計算を行なった結果，磁極表面については非線 形理論(7)の発生損失に近い值を示すことがわかった。

その結果をあとにして，本論文では有限要素法によ る損失計算值を非線形理論による值によって無次元化 を行なった。すなわち, 設計上, 必らずし有限要素 による計算を行なわなくても，突極形塊状磁極同期電 動機の損失分布および損失值の推定ができるしとが本 剑文により明らかにされだ。

\section{2. 究極形塊状磁極同期機の磁束分布}

塊状磁極内部に発生する損失を計算するため，塊状 磁極の磁気的非線形を考虑して，有限要素法によって 磁束分布を求める。以下，順化説明を行なうこととす る。

〈2·1〉有限要素法による計算の概要 塊状磁極 


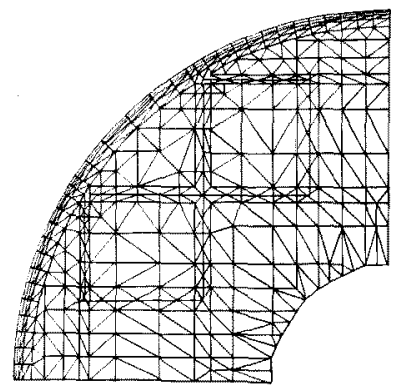

図 1 要素分割図

Fig. 1. FEM Subdivision.

部にうず電流が流れる場合，二次元問題として考える と，次式が成立する。

$$
\frac{\partial}{\partial x}\left(\frac{1}{\mu} \frac{\partial \boldsymbol{A}}{\partial x}\right)+\frac{\partial}{\partial y}\left(\frac{1}{\mu} \frac{\partial \boldsymbol{A}}{\partial y}\right)=j \omega \sigma \boldsymbol{A}-\boldsymbol{J}_{e}
$$

ここで，A 複素ベクトルポテンシャルで， $\mu$ は透 磁率，J：は印加電流で， $\sigma$ は導電率である。

座標系関して， $x$ 方向成分は回転方向， $y$ 方向は 半径方向とする。(1)式を有限要素法を用いて解くこ 之により，塊状磁極同期機の磁極内部のうず電流損を 求めることができる。

図 1 は有限要素法によって解析を行なう場合の, 塊 状磁極の要素分割図である。磁極の対称性を考虑して 一極分について解析を行なう。図1に招りる要素数は 758，節点数は 418 である。なお，解析の対象とした 塊状磁極同期機の定格は 4 極， $220 \mathrm{~V}, 3 \mathrm{kVA}, 50 \mathrm{~Hz}$ である。

図 1 の塊状磁極内部の各要素の透磁摔 $\mu$ は，まず有 限要素法に上る解加ら磁束密度 $B$ の絶対值を求好磁 極材料の磁気特性加ら $\mu$ を求めている。透磁率 $\mu$ の 值が収束する値をむって，その要素の透磁率としてい る。すなわ古, 塊状磁極材料の磁気特性より磁束密度 之比透磁率 $\mu_{r}$ との関係安求める。本論文に招りる磁 束密度 $B$ と比透磁萍 $\mu_{\mathrm{r}}$ との関数関係を次倸す。

$0 \leqq B \leqq 0.85, \mu_{r}=\alpha_{0}$

$0.85<B \leqq 1.1, \quad \mu_{r}=\alpha_{1}\left(B-\alpha_{2}\right)^{2}+\alpha_{0}$

$1.1<B \leqq 1.5, \quad \mu_{r}=\alpha_{3} B+\alpha_{4}$

1. $5<B \leqq 1.95_{0}, \mu_{r}=\alpha_{5} B^{2}+\alpha_{6} B+\alpha_{7}$

1. $95<B<\infty, \quad \mu_{r}=\exp \left\{\alpha_{8} B^{2}+\alpha_{9} B\right\}+1$

ここで， $\alpha_{i}(i=0,1,2, \cdots, 9)$ は塊状磁極材料の磁気 特性より求められる係数である。

さて, ベクトルポテンシャルより求めら机る磁束密 度 $\boldsymbol{B}$ は各要素について複菜数で与えられる。すなわ ち, 次式の形になる。

$$
\boldsymbol{B}=\left|B_{0}\right|+j\left|B_{1}\right|
$$

$B_{0}$ の $x$ 方向成分， $y$ 方向成分ををれぞれ $B_{0 x}, B_{0 y}$ とし， $B_{1}$ の $x$ 方向成分， $y$ 方向成分をそれぞれ $B_{1_{x}}$, $B_{1 y}$ とすると

$$
\begin{aligned}
& \left|B_{0}\right|=V \overline{B_{0 x^{2}}+B_{0 y}{ }^{2}} \\
& \left|B_{1}\right|=V \overline{B_{1 x}{ }^{2}+B_{1 y}{ }^{2}}
\end{aligned}
$$

従って，磁束密度 $B$ は次式により求めることがで きる。

$$
B=\sqrt{B_{0}^{2}+B_{1^{2}}^{2}}
$$

本論文の塊状磁極部の発生損失㐨よびトルクの計算 亿あたり端部の影響を考虑して求めている。すなおち 端末係数〔文献 (6)の (44) 式〕に上って固有抵抗值の 補正を行なっている。

次に境界条件について述べる。

本研究において，基本波による回転磁界中の塊状磁 極部の磁束分布を求めるため，その境界条件は，固定 子鉄心内径佂正弦波状にベクトルポテンシャル值を与 える。すなわ占，図2，図3に与えるべクトルポテン シャル值を示す。図2 は直軸位置におけるべクトルポ テンシャル分布，図了は横軸位置におけるべクトルポ テンシャル分布を示す。図2 亿扮ける $A_{d}$ は直軸位置 におけるエアギャップ部ベクトルポテンシャル最大值 である。また，图了における $A_{9}$ は横軸位圆における エアギャップ部ベクトルポテンシャル最大值である。

すなわち, エアギャップ磁束密度の最大位置に磁極

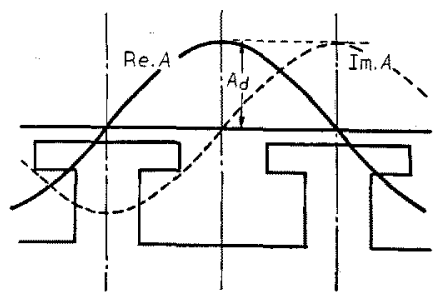

図 2 ベクトルポテンシャル值(直軸位置)

Fig. 2. Vector potential

(direct axis).

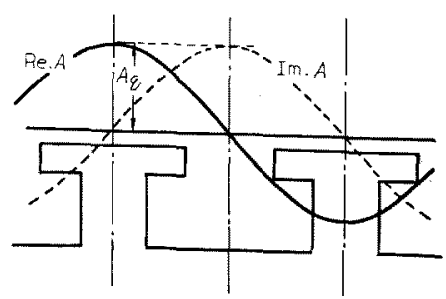

図 3 ベクトルポテンシャル值 (横軸位置)

Fig. 3. Vector potential (Quadrature axis). 
の中心がある場合（直軸位置）と，磁極と磁極の中間 位置（横軸位置）にエアギャップ磁束密度の最大值が ある場合とでは塊状磁極部敒発生する損失が翼なる。 本論文では現象が異なる二つの場合について磁極部の 損失計算を行なった。

なお，磁極の直軸位置および横軸位置におけるべク トルポテンシャルはエアギャップ部最大磁束密度で基 準化した值であるので，各すべりに対して適切なエア ギャップ磁束密度を与える。本研究においては，等価 回路を用いることによって，一次侧インピーダンスに よる電王降下を考慮してエアギャップ部最大磁束密度 を求めている。

$\langle 2.2\rangle$ 計算結果 有限要素法により, 突極形塊 状磁極同期電動機の各すべりに対する磁束分析を求め た。界磁コイルは開放とし，塊状鉄心部にうず電流が 発生している場合を計算している。

図 4 ，図 5 亿磁束分布の計算例を示す。図 4 洁すへ り $S=1$ で，直軸位置および横軸位置におりる磁束分 布である。図 5 はすへりり $S=0.2$ におりる計算例であ る。

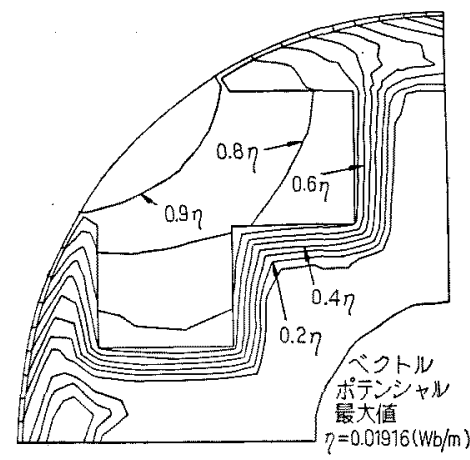

（a）声執位啚

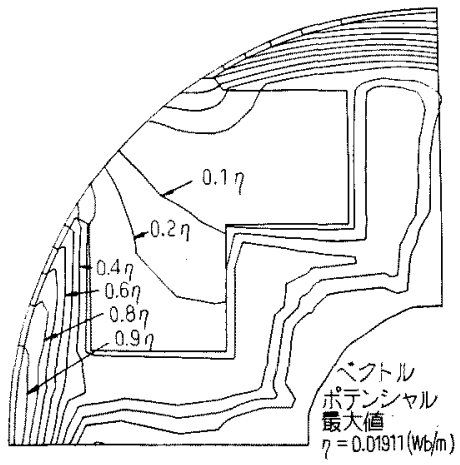

(b) 㘥軸位慨

図 4 磁束分布 $(S=1)$

Fig. 4. Flux distributions $(S=1)$.

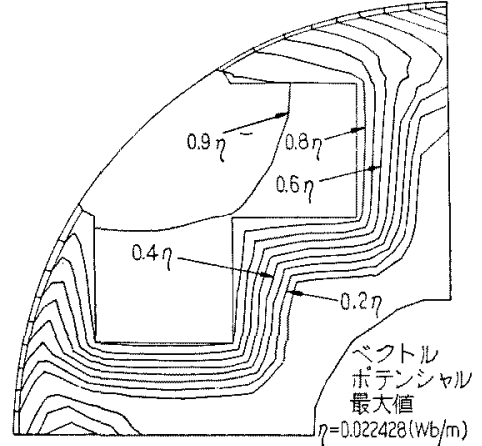

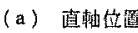

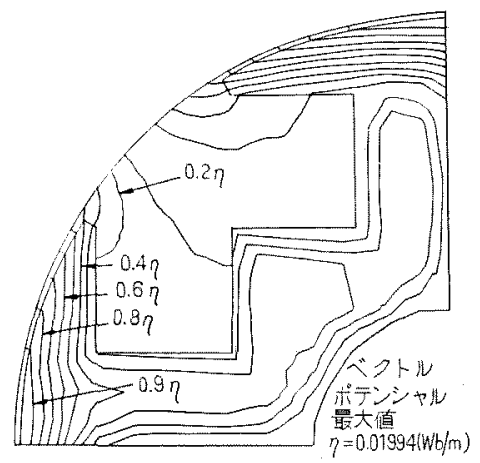

(b) 獚柚位䁌

図 5 磁束分布 $(S=0.2)$

Fig. 5. Flux distributions $(S=0.2)$.

図 4, 図 5 の比较により，すべりが少となる上磁束 がより樑く浸透し，磁極の深い位置に打りる回転磁界 に対する位相㺚れす少なくなることが示されている。

\section{3. 磁極内部の損失分布}

ここでは, 複菜ベクトルポテンシャルと損失計算式 との関係について考察し，本論文と関連のある非線形 理論(7)について述べる。

〈3.1〉 複素ベクトルポテンシャルと損失計算式 有限要素法傜々る磁束分布之塊状磁極内部汇発生す る損失との関係を明らか沉するため，マックスウエル の電磁界方程式を解己, 塊状磁極内の損失計算式を求 める。

$$
\begin{aligned}
& \text { まず，次に示す方程式(2)式〜（6)式より } \\
& \operatorname{rot} \dot{\boldsymbol{E}}=-\frac{\partial \dot{\boldsymbol{B}}}{\partial t} \\
& \dot{\boldsymbol{B}}=\mu_{0} \mu \dot{\boldsymbol{H}} \\
& \operatorname{rot} \dot{\boldsymbol{H}}=\dot{\boldsymbol{J}} \\
& \dot{\boldsymbol{J}}=\sigma \dot{\boldsymbol{E}}
\end{aligned}
$$




$$
\dot{\boldsymbol{E}}_{x}=\dot{\boldsymbol{E}}_{y} \equiv 0
$$

次式得られ， $E_{z}$ は $(8)$ 式化より求められる。

$$
\begin{aligned}
& \frac{\partial \dot{\boldsymbol{B}}_{y}}{\partial t}=\frac{\partial \dot{\boldsymbol{E}}_{z}}{\partial x} \ldots \ldots . . \\
& E_{z}=\int\left(\frac{\partial \dot{\boldsymbol{B}}_{y}}{\partial t}\right) d x .
\end{aligned}
$$

ここで，記号 $\boldsymbol{B}_{y}, \boldsymbol{E}_{x}$ は時間べクトルを示してい る。また， $\omega_{0}$ は電源周波数，x：は極対ピッチを示す あのさする。

ことで,

$$
\begin{aligned}
& \dot{\boldsymbol{B}}_{y}=B_{y} e^{\lrcorner \beta} \ldots \ldots \ldots \ldots . . . . \\
& \beta=\left(2 \pi / x_{0}\right) x-S \omega_{0} t
\end{aligned}
$$

と定め机ば，

$$
\dot{\boldsymbol{B}}_{z}=-\left(x_{0} / 2 \pi\right) S \omega_{0} \boldsymbol{B}_{y^{\prime}}
$$

を得る。すなわち，

$$
\therefore E_{x}=-\left(x_{0} / 2 \pi\right) S \omega_{0} R_{e}\left\{\boldsymbol{B}_{y}\right\}
$$

また，軸方向電流密度 $J$ : は次式上なる。

$$
J_{z}=-\left(x_{0} / 2 \pi\right) S \omega_{0} \sigma R_{e}\left\{\boldsymbol{B}_{y}\right\}
$$

よって瞬時值損失を $W$ 。で示すとすれば，

$$
W_{c}=(1 / \sigma) J_{z^{2}}=\sigma\left(\frac{x_{0}}{2 \pi} S \omega_{0}\right)^{2}\left\{R_{e}\left(\boldsymbol{B}_{y}\right)\right\}^{2}
$$

として得られる。

次に，有限要亚法により求められるべクトルポテン シャル值と塊状磁極内部に発生する損失との関係を明 らかにする。

ベクトルポテンシャルは次式で定義される。

$$
\boldsymbol{B}=\operatorname{rot} \boldsymbol{A}
$$

(2) 式〜 (5) 式と(15) 式上り， $\boldsymbol{E}_{x}$ は,

$$
\boldsymbol{E}_{z}=-\frac{\partial \boldsymbol{A}_{z}}{\partial t}
$$

となる。ここで,

$$
\boldsymbol{A}_{z}=\boldsymbol{A}_{1}(x, y) e^{j \beta}
$$

とおけば,

$$
\boldsymbol{E}_{z}=j S \omega_{0} \boldsymbol{A}_{1} e^{j \beta}
$$

また，(15) 式〜 (17)式より

$$
\begin{aligned}
& B_{y}=-\frac{\partial}{\partial t} \boldsymbol{A}_{1} e^{j \beta} \ldots \ldots \ldots . . . \\
& \therefore \boldsymbol{B}_{y}=-j\left(\frac{2 \pi}{x_{0}}\right) \boldsymbol{A}_{1} e^{j \beta} \ldots \\
& \therefore \boldsymbol{A}=\boldsymbol{A}_{1} e^{j \beta}=j\left(\frac{x_{0}}{2 \pi}\right) B_{y}
\end{aligned}
$$

更に，(10)式在(15)式に代入し，整理主ると

$$
\boldsymbol{E}_{z}=j S \omega_{0}\left\{\boldsymbol{A}_{1} e^{j \beta}\right\}=-\left(\frac{x_{0}}{2 \pi}\right) S \omega_{0} \boldsymbol{B}_{y}
$$

を得る。

本論文における有限要素法は，一次要素を用いてい るので，磁束密度 $B$ は三角要絜内で一定となる。こ のため $B$ を用いて損失分布を計算するよりも，位置 の関数であるべクトルポテンシャル $A_{1}(x, y)$ を用い て損失計算する方が精度良く計算することができる。 徉って，磁束密度 $B$ を用いた損失計算式は(14)式で 求められているが，次にベクトルポテンシャル $\boldsymbol{A}$ を 用いた撌失計算式老求力る。ま大瞬時值の損失は (14)

式，(20)式より(23)式で与えられる。

$$
W_{c}=J^{2}{ }_{z} / \sigma=\sigma\left[R_{e}\left(j S \omega_{0} \boldsymbol{A}_{1} e^{j \beta}\right)\right]^{2}
$$

次化，損夫の時間平均值を求める。まず，ベクトル ポテンシャル $\boldsymbol{A}$ は次式のように変形さ机る。

$$
\begin{aligned}
\boldsymbol{A}= & \boldsymbol{A}_{1} e^{j \beta}=\left(A_{01}+j A_{02}\right) e^{j \beta} \\
= & \left(A_{01} \cos \beta-A_{02} \sin \beta_{1}\right)+j\left(A_{02} \cos \beta\right. \\
& \left.+A_{01} \sin \beta\right) \ldots \ldots \ldots \ldots \ldots \ldots \ldots \ldots . . . \ldots \ldots \ldots \ldots \ldots \ldots
\end{aligned}
$$

従って, 損失 $W$ 。 は

$$
\begin{aligned}
W_{c}= & \sigma\left(S \omega_{0}\right)^{2}\left(A_{02}{ }^{2} \cos ^{2} \beta+A_{01}{ }^{2} \sin ^{2} \beta\right. \\
& \left.+2 A_{01} A_{02} \cos \beta \sin \beta\right) \ldots \ldots \ldots \ldots .
\end{aligned}
$$

を得る。ここで, 平均損失を $W$ とすると

$$
\begin{aligned}
W & =\frac{1}{T} \int W_{c} d t=\frac{1}{\omega T} \int_{0}^{2 \pi} W_{c} d \omega t \\
& =\frac{1}{2}\left(S \omega_{0}\right)^{2} \sigma\left(A_{01}{ }^{2}+A_{02^{2}}\right)^{2}\left(W / \mathrm{m}^{2}\right)
\end{aligned}
$$

$$
\begin{aligned}
& \text { ここで, } \\
& \quad \boldsymbol{A}_{1}=A_{01}+j A_{02} \ldots \ldots \ldots \ldots \ldots \ldots \\
& \left|\boldsymbol{A}_{1}\right|=\left(A_{01}{ }^{2}+A_{02}{ }^{2}\right)^{1 / 2} \ldots \ldots \ldots \ldots \\
& \therefore W=\frac{1}{2}\left(S \omega_{0}\right)^{2} \sigma\left|\boldsymbol{A}_{1}\right|^{2}\left(\mathrm{~W} / \mathrm{m}^{3}\right)
\end{aligned}
$$

このように複素ベクトルポテンシャルの絶対值の二 乗を求め係数 $(S \omega 0)^{2} \sigma / 2$ を乗ずることにより平均損失 を計算することができる。

〈3.2）韭線形理論の概要本研究では有限要素 法による計算結果之非線形理論による結果とを比較し ているので, 説明の都合上, 非線形理論 $(7)$ 概要を述 べることとする。

塊状鉄心内の磁気特性を次式で近似する。

$$
\begin{aligned}
& B_{x}=K H_{x^{1-2 / n}} \\
& B_{y}=\mu_{0} \mu_{y} H_{y} .
\end{aligned}
$$

損失計算式は次式で与元ら机る。

$$
W=\frac{\omega^{2} K^{2} a_{0}^{2 n-4}}{2 \rho\left\{(n-1)^{2}+A^{2}\right\}} Z^{2 n-2}\left(W / m^{3}\right)
$$


記号 $A, a_{0}$ は次式により与えられる。

$$
\begin{aligned}
A= & (2 n-1) m /(2 \sigma \omega) \ldots \ldots \ldots \ldots \ldots \ldots \ldots \\
a_{0}= & \{\sigma \omega /(2 n-1)\} \sqrt{2 K / m} \ldots \ldots \ldots \ldots \ldots \\
m= & -\frac{1}{\mu_{0} \mu_{z}}\left(\frac{\pi}{\tau}\right)^{2} \\
& +\sqrt{\left\{\frac{1}{\mu_{0} \mu_{z}}\left(\frac{\pi}{\tau}\right)^{2}+\frac{4 n(n-1) \omega^{2} \sigma^{2}}{(2 n-1)^{2}}\right.}
\end{aligned}
$$

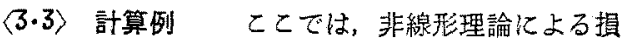
失計算で使用する $B H$ 曲線，非線形理諭による損失 計算值，有限要素法による損失の訢算例について述心 名。

非線形理論計算において, 磁極部の磁性材料の実测 の $B H$ 曲線に近い曲線として次式で与える。

$$
B=0.4 H^{0.16}
$$

次に, 非線形理諭の回転子半径仮想長 $Z 0$ 定検討与 了。

非線形理論の特街は，とのZ゙である。この $Z_{0}$ は ポールピッチ，磁束密度，B-H曲線などで決定され それでれ異なる值を用いると変動する。

以下に， $B_{z 0}$ 亡 $Z_{0}$ の関䋆を示し，供試機の数値を 代入し， $Z_{0}$ を求める。

$$
\left|B_{y 0}\right|=\left(\frac{\pi}{\tau}\right) \frac{K a_{0}^{n-2}}{\sqrt{(n-1)^{2}+A^{2}}} Z_{0}^{n-1}
$$

でるるら

$$
g_{1}=\left\{\left(\frac{\tau}{\pi}\right) \frac{\nu \overline{(n-1)^{2}+A^{2}}}{K a_{0}{ }^{n-2}}\right\}^{1 / n-1}
$$

霆に，Z0 次式で与えられる。

$$
Z_{0}=g_{1}\left|B_{z 0}\right|^{1 /(n-1)}
$$

有限要素法において，すべり $S=1$ でエアギャップ 部最大磁束密度は直軸位置で $0.479 \mathrm{~T}$ を使用した。 直軸における磁束浸透深さを $Z_{0_{d}} \subset し ，$ 横軸におけ

\begin{tabular}{|c|c|c|c|}
\hline 記 号 & 数隹 & 記 号 & 值 \\
\hline$\tau \quad(m)$ & 0.1241 & $m_{0}$ & $0.708 \times 10^{9}$ \\
\hline$\sigma(v / m)$ & $2.341 \times 10^{6}$ & $A$ & 1.812 \\
\hline$\mu_{z}$ & 900 & $a_{0}$ & $6,569.5$ \\
\hline$K$ & 0.4 & $g_{1}$ & 0.030038 \\
\hline$n$ & 2.381 & & \\
\hline
\end{tabular}
る磁束浸透梁さを $Z_{0}$ とする。数值例を表 1 亿示す。

园6に $Z / Z_{0_{d}}$ Ł $W / W_{0 d}$ との計算結果を示してい る。 $Z=Z_{0}$ （磁極表面部）において直軸位置の損失の 基準徝夺 $W_{0}=W_{0 d}$ とし，横軸における損失の基準 值を $W_{0}=W_{0_{q}}$ と方手。 $W_{0 d}, W_{0_{q}}$ の值は， $W_{0_{d}}=$

表 1 数 值 例

Table 1. Numerical example.

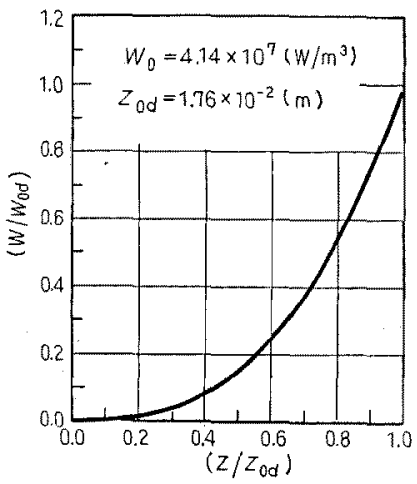

图 6 損失計算(非線形理諭)

Fig. 6. Loss by Non-linear theory.

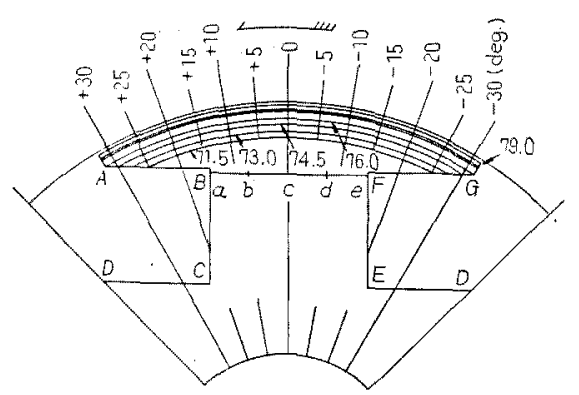

図 7 磁極位置説明図

Fig. 7. Symbol of position of solid pole for explanation.

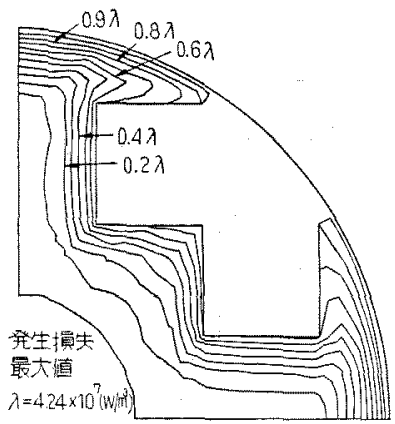

四 8 損失分布(声檕位置)

Fig. 8. Loss distribution (Direct axis).

$4.14 \times 10^{7} \mathrm{~W} / \mathrm{m}^{3}, \quad W_{0_{q}}=1.67 \times 10^{7} \mathrm{~W} / \mathrm{m}^{3}$ である。

図 7 は塊状磁極部の損失諳算にあたり，磁極位置の 説明用の記号㧍よび寸法を示している。

図8，図9 はそれぞれ，有限要素法による直軸书よ び横軸におりる損失分布を示している。磁極表面部は 損失が大で，磁極表面部より哚くなるにつれて損失が 


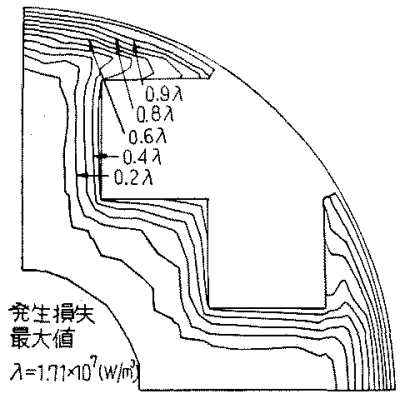

図 9 損失分布 (横軸位犆)

Fig. 9. Loss distribution (Quadrature axis).

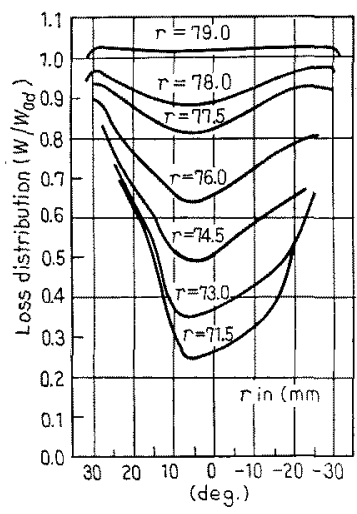

因 10 損失分布 (直軸位置, $r=$ 一定)

Fig. 10. Loss calculation.

(Direct axis, $r=$ const).

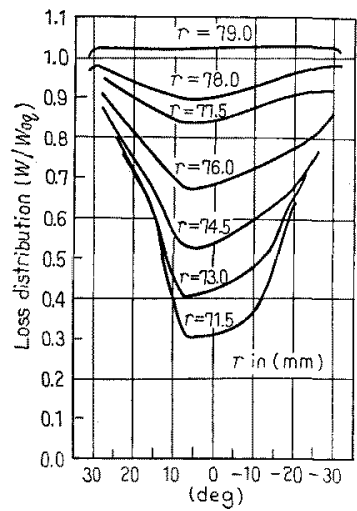

因 11 損失分布 (横軸位置, $r=$ 一定)

Fig. 11. Loss calculation

(Quadrature axis, $r=$ const).

減少する。

図 10, 図 11 は磁極片内部の損失を直軸, 横軸それ ぞれ $W_{0_{d}}, W_{0_{q}}$ で基準化し, 半径 $r$ 亿対する損失值

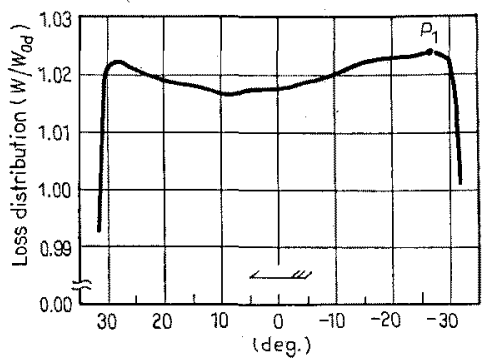

図 12 磁極表面部の損失 (直軸位置, $S=1$ )

Fig. 12. Loss on solid pole surface (Direct axis, $S=1$ )

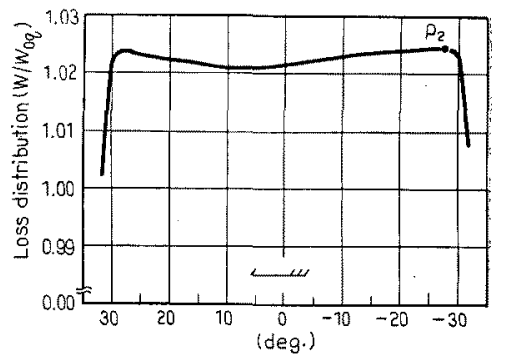

図 13 磁極表面部の損失 (熿軸位置, $S=1$ )

Fig. 13. Loss on solid pole surface (Quadrature axis, $S=1$ ).

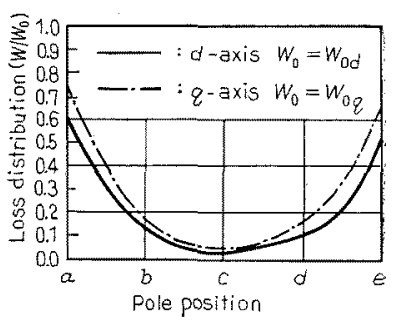

図 14 磁極内部の損失 $(S=1)$

Fig. 14. Loss in solid pole $(S=1)$.

を示している。同じ半径 $r$ に対して，直軸位置と横軸 位置では，最大磁束密底，磁束分布招よびうず電流通 路が異なるため発生損失は異なる。

图12，図 13 は直軸，横軸に找ける磁極表面部の損 失 $W$ をそれぞれ $W_{0 d} ， W_{0 q}$ にて基準化して示して いる。図12の $P_{1}$ 点, 図13の $P_{2}$ 点にてそれでれ最 大值を示している。その值はほぼ1.024である。従っ て非線形理論による計算値上有限要素法に上る計算值 の差は最大でほ涩 $2.4 \%$ の差がある。従って，磁極表 面部の磁極の中心部分での表面損失は非線形理論仙よ り精度良く計算が可能と考える。また，図 12 ，図 13 の結果加ら，磁極表面部の損失分布は回転方向上反対 


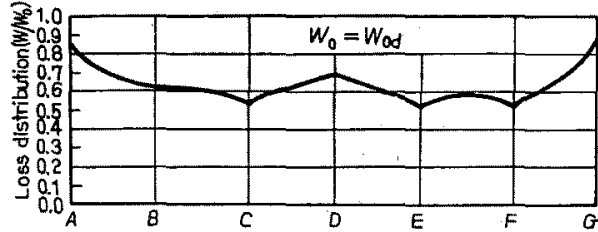

磁極側面韵位管

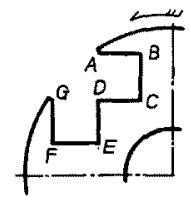

因 15 磁極側面部の損失 (直軸位置)

Fig. 15. Loss on pole side (Direct axis, $S=1$ ).

の磁極部の損失が大で，中央部ではやや小となること がわかる。

図 14 は磁極部内部の損失分布，図 15 は塊状磁極 側面部における損失分布を示す。

本研究において，基準とする損失密度 $W_{0 d}$ および $W 0_{q}$ は一般式しして求められる量であるので, 以上 に示した有限要素法による結果により，突極形塊状磁 極の揾失分布を知石指針加得られた。

\section{4. ポインティングベクトル計算と非同期 トルク計算}

有限要素法により得られた結果を測定値と比較する ため, 有排要慗法により求めたトルクと実測値との比 較を行なった。すなわち，損失と二次入力との関係， 二次入力とトルクとの関係より，有限要素法による嗄 失からトルクを計算することがでまる。すなわち，塊 状磁極同期電動譏の二次入力 $P_{i}$ とトルク $T$ の関係 は次式で与えられる。

$$
T=P_{i} / \omega_{0}
$$

但し, $\omega_{0}=2 \pi f_{0}$ : 電源角周波数

また，固定子(一次側)からエアギャップを介して回 転子 (二次側) に流入する三次入力は複素ポインティン グベクトルの概念を導入することによって求めるてと ができる ${ }^{(3)(4)}$ 。なお，固定子坐標柔における二次入力

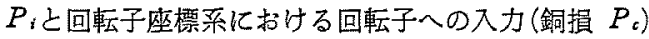
との関係は次式により求められる。

$$
P_{i}=P_{c} / S
$$

次に，計算結果について述へる。各すべりについて 直軸位葍，樭軸位置それぞれについて有限要素法によ り $P_{c}$ を求め，(41) 式より $P_{i}$ を求めトルクを部算し た。図 16 は有限要素法により求めたすべりトルク特 性である。すべり 0.5 近辺を除いては測定值之摽算值

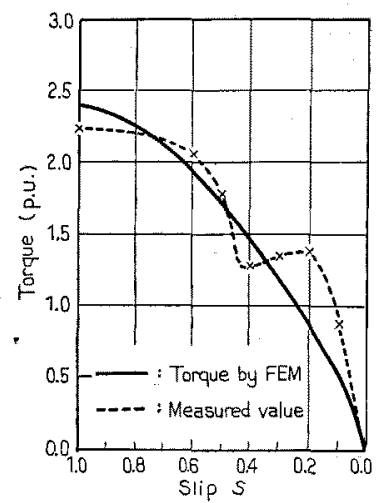

図 16 トルク計算值

Fig. 16. Torque calculation by FEM.

はよく合っている。なお，すべり 0.5 付近において計 算値と測定值はかなり翼なる。

例えば文献（6）にみられるように，突極機の非同期 運転に斿いてすべりが0.5付近においてトルク值が変 化することが知られている(ゲルゲス現象)。とれは固 定子巻線の抵抗值が直接関係するためである。

本論文における塊状磁極部の損失部算にあたっで， エアギャップ部の磁束密度を知る必要がある。

固定子巻線のスロット漏れりアクタンスおよびコイ ル端漏れリアクタンスの影響すなわち，固定子鉄心に ついては磁気的非線形の影響は少ないと考えられる。

本研究では固定子側のインピーダンス電在降下を等 価回路上で求めエアギャップ磁束密度を求めている。 従ってエアギャップ磁束密度は精度良く計算できる。 固定子鉄心を含めた有限要素法による解析は要索数, 節点数がそれだけ多くなるので計算時間が増加する。 すなわち，本詥文の塊状磁極部の損失計算において固 定子鉄心を含めた有限要素法による解析を行なう必要 がない。

図 16 を計算した目的は，図8〜㘝 15 の損失の計 算結果を評価するととが目的である。従って，すべり $S=0.5$ 付近のトルク計算の問題は本諭文の対象外之 する。

\section{5.あとがき}

塊状磁極司期電動機の限界設計にあたり，磁極部に 発生する損失による温度上昇を知るととが重要な問題 となっている。本諭文は非同期運転時の塊状磁極同期 電動機の磁極に発生する損失を有限琶素法により検討 を行なったるのである。複雑な滋極形状を有する塊状 磁極同期電動機の非同期運転時の損失に関して往来， 
解析解が求められていない。しかしながら有限要絭法 による損失分布の計算結果は何らかの手段で，一般性 を持つことが望ましい。

本研究では，円筒形状汶対する非線形理論(7)を用い て塊状鉄心部の損失を計算し，その計算結果上有限要 糸法による磁気的非線形を考慮した損失之の比較劣行 なった。その結果, 有限要素法による計算と非線形理 諭との関連が明らかになり有限要票法による卦算にあ る程度の一般性をもたせることができだすなるち， 複雜な磁極形状を考慮した磁束分布は，円筒形状の回 転子に対して求めた非線形理論では十分に計算するこ 上がむつかしい。彷って，本論文では，実用的な手法 として塊状磁極部の曲率および磁極形状による影響を 有限要素法を使用した計算により補正を行なったあの である。

この種の問題の計算に固定子鉄心を含めた有限要素 法解析加考えられるる ${ }^{(9)}$ 。この場合, 二次元問題で考え る限り、コイル端瘺れリアクタンスは数式によって計 算する必要がある。また，固定子スロット漏れリアク タンスは計算式による解析解により精度良く計算でき る性質のあのである。また，固定子鉄心を含めた有限 要素法による損失䂥算を塊状磁亟の非線形磁気特性を 考虑して解を求める場合, 要素数, 節点数, バンド幅 が大となり，計算時間が大幅に增えるという欠点もあ る。

塊状磁極同期電動機におりる損失計算にあたり，塊
状磁極部の磁束分布が重要な間題である。

本論文は夷用的な見地加ら，従来研究の行なわれて きて, 計算例の䅱富な等価回路(1)(2)(6)を併用する手法 によって損失計算の検討を行なった。

本論文に示すように有限要素法計算により，複藮な 磁極形状を考慮した塊状磁極内部の損失を求めること ができた。

終りに，日頃御支援頂いている埼玉大学天野宽德 教授に謝意を表します。(昭和 56 年 11 月 25 日受付)

\section{文献}

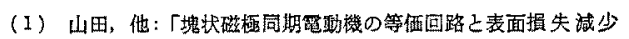
効果」電学誈B 99.765 (昭 54-12)

（2）山田・小會：「塊状磁極同期機の等価回路之韭同期特性了昭 52 㠿気学会回転機研究会 No. RM-77-4

（3）山田・金井：「塊状磁極同期電動機の有限要素法による非同 期特性」昭 56 雷氛学会全大 No. 700

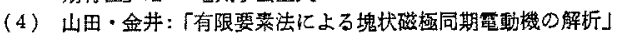
昭 56 氜気学会東京文大 No. 278

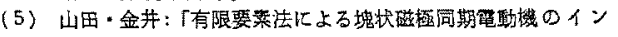
ピーダンス計算」党学誌 B 101，569 (昭 56-9)

(6) Nicolaide: "Untersuchung der Charakteristiken der Synchronmachinen mit massiven Schenkelpolen bei asynchrorem Anlauf" Arch. Elektrotech, 54, p. 108 (1971-2)

(7) Pillai : "Fundamental Frequency Eddy-Current Loss due to Rotating Magnetic Field, Pt 1", Proc. Instn Elect. Engrs, 116, 3, p. 407 (1969)

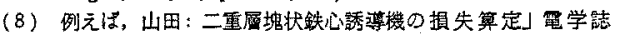
91, 947 (昭 46-6)

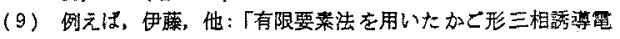
趿機の始動電流解析了雱学諭 B 99，41 (昭 54-1) 